\title{
Travellers returning with measles from Thailand to Finland, April 2012: infection control measures
}

\author{
A Kantele (anu.kantele@hus.fi) ${ }^{1,2}$, K Valtonen³, I Davidkin³, T Martelius ${ }^{1}$, N Võželevskaja ${ }^{4}$, K Skogberg $^{1}$, I Liesmaa ${ }^{1}$, \\ 0 Lyytikäinen ${ }^{3}$ \\ 1. Department of Medicine, Division of Infectious Diseases, Helsinki University Central Hospital, Helsinki, Finland \\ 2. Department of Clinical Medicine, University of Helsinki, Helsinki, Finland \\ 3. Department of Infectious Disease Surveillance and Control, National Institute for Health and Welfare, Helsinki, Finland \\ 4. Northern Service of the Health Board, Tallinn, Estonia
}

Citation style for this article:

Kantele A, Valtonen K, Davidkin I, Martelius T, Võželevskaja N, Skogberg K, Liesmaa I, Lyytikäinen O. Travellers returning with measles from Thailand to Finland,

April 2012: infection control measures. Euro Surveill. 2012;17(22):pii=20184. Available online: http://www.eurosurveillance.org/ViewArticle.aspx?Articleld=20184

Countries with no autochthonous measles run the risk of the virus being imported by travellers and transmitted to unprotected citizens. In April 2012, two travellers from Finland and one from Estonia were diagnosed with measles after returning from Phuket, Thailand. They were contagious on their return flights and subsequently exposed several individuals, prompting extensive infection control measures. Two secondary cases were detected: one child who had received one vaccine dose and another who was fully vaccinated.

In April 2012, three people who had travelled from Finland contracted measles after their return from Phuket, Thailand. We describe here the measures taken for these three cases and the identification of secondary cases.

Case 1 was an Estonian woman in her early 30 siving in Finland, who may have received one dose of measles vaccine during childhood. She flew to Phuket on 23 March and her symptoms started on 3 April. When flying back to Helsinki on 6 April, she had both a fever and a rash. The next day she was referred from a healthcare centre to Hospital A. It was only the following day (8 April), after she had been admitted to infectious diseases Hospital $B$, that measles was suspected. The diagnosis was confirmed (positive serum IgM and detection of measles virus RNA by PCR from oral fluid, throat and urine samples) on 12 April.

Case 2, an unvaccinated Finnish woman in her early 405 , had no history of measles. She took the same flight to Phuket as Case 1 and developed fever on the morning of her return flight on 6 April. She was admitted to Hospital C on 8 April. The next day, measles was suspected and she was transferred to infectious diseases Hospital B. The diagnosis was confirmed (positive serum IgM and detection of measles virus RNA by PCR from oral fluid, throat and urine samples) on 12 April.
Case 3, an Estonian woman in her early 30s, may have received one dose of measles vaccine during childhood. Having arrived in Phuket on 19 March, she developed fever and began coughing and sneezing on the day of her flight home, 2 April. She then travelled by ferry from Helsinki to Tallinn, Estonia, and soon returned to her work as schoolteacher. Her symptoms persisted and she was first examined by a family doctor on 5 April, then admitted to Hospital D and subsequently to infectious diseases Hospital E, where finally measles was suspected. The diagnosis was confirmed (positive serum IgM) seven days later, on 13 April.

It is noteworthy that all three cases stayed at different hotels in Thailand and had no known contact with one another besides the flights taken by Cases 1 and 2 .

\section{Background}

Outbreaks of measles still occur repeatedly in Europe in many areas where vaccination coverage is not sufficiently high $[1,2]$. In countries with high coverage, such as Finland (295\%) [3], the small proportion of unprotected citizens (unvaccinated or not having had the disease) are virtually at no risk of contracting the virus, as it has ceased to circulate among the population. However, such individuals may get infected when travelling and, after their return, transmit the virus to others who are also unprotected, as has been seen in Finland (Table 1). Thus not even high vaccination coverage will prevent local clusters of the disease [3]. Once measles is suspected, infection control is urgently needed to prevent its potential spread. Notably, however, the suspicion of measles can be delayed in countries with no autochthonous measles, since clinicians may no longer recognise the disease.

\section{Control measures}

The national recommendations advise all travellers to check their vaccination status, including that for mumps-measles-rubella (MMR) vaccine before travel, 
yet, our experience is that short-term travellers to Thailand, like our patients, seldom seek pre-travel advice.

In all three cases, once measles was suspected, the patients were immediately placed in isolation with airborne precautions. Doctors responsible for communicable disease control in Finland and Estonia, and the National Institute for Health and Welfare in Finland were also informed about the cases. All three cases had all been contagious on their return flights, and had afterwards, in their home country, been in contact with several individuals. Upon confirmation of the diagnoses of Cases 1 and 2 on 12 April, the doctor in Hospital B, having first interviewed the patients, alerted Hospitals $A$ and $C$, as well as the communicable diseases doctor responsible for all health centres, to begin contact tracing (Table 2 ).

After receiving the flight number of Cases 1 and 2 on 12 April, the National Institute for Health and Welfare contacted the travel agency responsible for the trip. The travel agency provided the telephone numbers and email addressed for all passengers. SMS (text) messages were sent on the same day alerting them to read their emails specifying the symptoms of measles. Should any passenger develop any of the symptoms, they were advised to call their health centres for

\section{TABLE 1}

Measles cases in Finland, January 1996-May 2012 (n=47)

\begin{tabular}{|c|c|c|}
\hline Year & Number of cases $^{a}$ & Country visited by index cases \\
\hline 1996 & 0 & - \\
\hline 1997 & 0 & - \\
\hline 1998 & 1 & Brazil \\
\hline 1999 & 0 & - \\
\hline 2000 & 2 & Sweden $(n=1)$, India $(n=1)$ \\
\hline 2001 & 1 & Papua New Guinea \\
\hline 2002 & 0 & - \\
\hline 2003 & 0 & - \\
\hline 2004 & 0 & - \\
\hline 2005 & 1 & Italy \\
\hline 2006 & 0 & - \\
\hline 2007 & 0 & - \\
\hline 2008 & 5 & $\begin{array}{c}\text { Thailand }(n=1) \text {, Switzerland }(n=1) \text {, } \\
\text { England }(n=3)\end{array}$ \\
\hline 2009 & 2 & Iraq $(n=1)$, Italy $(n=1)$ \\
\hline 2010 & 5 & Senegal $(n=1)$, Italy $(n=1)$ \\
\hline 2011 & 27 & France $(n=3)$, Latvia/Sweden $(n=1)$ \\
\hline 2012 & 3 & Thailand $(n=2)$ \\
\hline
\end{tabular}

a Index cases and secondary cases are included. guidance. Post-exposure prophylaxis (immunoglobulin or MMR vaccination) was no longer an issue as a week had passed since the flight.

On 12 April, the Finnish Early Warning and Response System (EWRS) team was notified about Case 3 in Estonia by the Estonian EWRS team, who also provided the flight number and all passengers were informed the same way as described above. A decision was made not to undertake contact tracing among ferry passengers.

In Finland, the National Institute for Health and Welfare sent emails to all healthcare districts informing them about the cases as well as the national guidelines [4] on 13 April. In the two countries, a total of 772 persons were reached and 21 of them, mainly health professionals, were given post-exposure prophylaxis (Table 2). Contact tracing revealed two secondary cases. The first, a 9-year-old pupil at the school in Estonia where Case 3 worked, had previously received one dose of MMR vaccine. The second, a fully vaccinated 13 -yearold in Finland, had taken the same flights as Cases 1 and 2 . The child's symptoms started on 16 April, implying that he could have contracted the disease already in Thailand.

The virus isolated from Cases 1 and 2 belonged to genotype D8, known to be circulating in Thailand (MeaNS, http://www.who-measles.org).

\section{Discussion}

In Finland, circulation of measles virus ceased in the mid-1990s [3]. All reported cases since 1996 have been laboratory confirmed, the source of infection has been traced and infection control measures taken [3] (Table 1). Despite the relatively large number of travellers to and from Finland (annual average of 5 million and 6.4 million, respectively) [3], measles cases have been rare, contracted mostly in other European countries (Table 1). In Thailand, despite the national immunisation programme, measles outbreaks still occur occasionally in both rural and urban areas [5]. Over 100,000 flights are taken by Finns to Thailand every year [6], yet only one measles case has been reported among travellers returning from Thailand, in 2008 , before the cases reported here (Table 1 ). It is noteworthy that on 14 May 2012, measles was reported also in a Russian traveller having recently returned from Thailand [7].

In the present instance, the diagnostic tests were delayed due to the Easter holidays and a misunderstanding at the laboratory. Even if further transmission from the index cases had been blocked by isolating the patients, the time window for post-exposure prophylaxis proved too long for many contacts. Despite this, those who had not had measles or two doses of MMR vaccine were, of course, advised to ensure that their vaccination series were completed. Finns born between 1960 and 1975 have not always received the vaccines or had the disease; many healthcare workers 


\section{TABLE 2}

Persons born after $1960^{\mathrm{a}}$ reached through contact tracing and post-exposure prophylaxis administered, Finland and Estonia, April $2012(\mathrm{n}=772)$

\begin{tabular}{|c|c|c|c|c|}
\hline \multirow{2}{*}{ Site and group of individuals traced } & \multirow{2}{*}{$\begin{array}{c}\text { Number of } \\
\text { persons traced }\end{array}$} & \multirow{2}{*}{$\begin{array}{l}\text { Number of persons vaccinated with } \\
\text { two doses of MMR vaccine or measles } \\
\text { verified /number of persons with } \\
\text { information available }\end{array}$} & \multicolumn{2}{|c|}{ Post-exposure prophylaxis administered } \\
\hline & & & Immunoglobulin & MMR vaccine \\
\hline Aircraft 1 & $290^{b, c}$ & NA & 0 & 0 \\
\hline Aircraft 2 & $290^{b, c}$ & NA & 0 & 0 \\
\hline \multicolumn{5}{|l|}{ Case 1 (in Finland) } \\
\hline \multicolumn{5}{|l|}{ Hospital A } \\
\hline Emergency unit patients & 2 & $2 / 2$ & 0 & 0 \\
\hline Radiology staff/patients & 4 & $3 / 3$ & 0 & 0 \\
\hline Healthcare staff & 14 & $13 / 13$ & 0 & 0 \\
\hline Healthcare centre staff/patients & 16 & $8 / 12^{c}$ & 1 & 1 \\
\hline \multicolumn{5}{|l|}{ Hospital B } \\
\hline Healthcare staff & 2 & $1 / 2$ & 0 & 1 \\
\hline Family and friends & 4 & $2 / 4^{\mathrm{c}}$ & 0 & 0 \\
\hline Total & 42 & $29 / 36^{c}$ & 1 & 2 \\
\hline \multicolumn{5}{|l|}{ Case 2 (in Finland) } \\
\hline \multicolumn{5}{|l|}{ Hospital C } \\
\hline Emergency unit patients & 12 & $9 / 12$ & 3 & o \\
\hline Patients on same ward & 1 & $0 / 1$ & 0 & 1 \\
\hline Radiology staff/patients & 5 & $5 / 5$ & 0 & 0 \\
\hline Visitors & 2 & $1 / 2$ & 1 & 0 \\
\hline Healthcare staff & 31 & $18 / 31$ & 0 & 13 \\
\hline Family and friends & 6 & $6 / 6$ & 0 & 0 \\
\hline Total & 57 & $39 / 57$ & 4 & 14 \\
\hline \multicolumn{5}{|l|}{ Case 3 (in Estonia) } \\
\hline \multicolumn{5}{|l|}{ Family practice } \\
\hline Personnel & 2 & $1 / 2^{c}$ & 0 & 0 \\
\hline Other patients & 3 & $2 / 3^{c}$ & 0 & 0 \\
\hline Ambulance staff & 3 & $2 / 3^{c}$ & 0 & o \\
\hline \multicolumn{5}{|l|}{ Hospital D } \\
\hline Healthcare staff & 5 & $2 / 5^{c}$ & 0 & 0 \\
\hline \multicolumn{5}{|l|}{ Hospital E } \\
\hline Healthcare staff & 17 & $10 / 17^{c}$ & 0 & 0 \\
\hline Family and friends & 3 & $2 / 3^{c}$ & 0 & 0 \\
\hline Colleagues at school & 10 & $2 / 10^{c}$ & 0 & o \\
\hline Pupils at school ${ }^{d}$ & 50 & $49 / 50^{c}$ & 0 & 0 \\
\hline Total & 93 & $70 / 93^{c}$ & 0 & 0 \\
\hline Grand total & $77^{2}$ & $138 / 186^{c}$ & 5 & 16 \\
\hline
\end{tabular}

MMR: mumps-measles-rubella; NA: not available.

a In Finland, most individuals born before 1960 have had measles and are therefore considered immune.

b Includes passengers of all ages on board the plane.

c Those considered susceptible, but only reached more than 72 hours after the exposure were (i) informed about the symptoms of measles, (ii) instructed to call their healthcare centre, should any symptoms occur, and (iii) instructed to ensure that their MMR vaccinations were complete.

d Children aged 7-9 years vaccinated with one dose of MMR vaccine (second dose planned at the age of 13 years). 
may belong to this age group, which is reflected in the numbers of unprotected individuals among healthcare staff in Hospital C (Table 2).

It should be noted that one of the secondary cases was a child who had received two vaccine doses. It appears that the child had seroconverted earlier, since measles IgG antibody level was relatively high on 20 April, i.e. only four days after the onset of the symptoms. Measles has, although rarely, been described in vaccinees with earlier documented seroconversion [8-13].

On this occasion, the process of reaching the flight passengers ran exceptionally smoothly. The travel agency readily provided both telephone numbers and email addresses for all passengers on the two charter flights. Emails and SMS messages were swiftly arranged. Information about individuals with infectious measles on an aircraft usually arrives too late, and passenger lists are not easily available, as was the case with travellers who had travelled on the same ferry as Case 3. If so, a press release is the most efficient means of contacting people.

Travellers returning infected may occasionally signal ongoing outbreaks in their destination countries. International networks alert their members about cases in the various countries. When reporting our cases on the European Network for Tropical Medicine and Travel Health (TropNet) member site, we learned that no outbreaks of measles had been identified in Thailand as yet (Dr Jiri Beran, personal communication, 26 April 2012). While both flights with the measles cases on board were destined for Finland, presumably flying mostly Finnish passengers, information on the flight carrying Case 3 relied entirely on the Estonian EWRS team reporting their case. This accentuates the importance of accurate surveillance and international networking as central tools for infection control.
1. Moss WJ, Griffin DE. Measles. Lancet. 2012;379(9811):153-64.

2. Muscat M, Bang H, Wohlfahrt J, Glismann S, Mølbak K; EUVAC. NET Group. Measles in Europe: an epidemiological assessment. Lancet. 2009;373(9661):383-9.

3. Davidkin I, Kontio M, Paunio M, Peltola H. MMR vaccination and disease elimination: the Finnish experience. Expert Rev Vaccines. 2010;9(9):1045-53.

4. National Institute for Health and Welfare (THL). Toimenpideohje torjuntatoimista tuhkarokkotapauksen yhteydessä. [Guidelines for infection control measures against measles]. Helsinki: THL; 7 June 2011. Finnish. Available from: http://www.thl.fi/ thl-client/pdfs/oadda5do-d43f-4ed6-ad4c-eodga330da14

5. Tharmaphornpilas $P$, Yoocharean $P$, Rasdjarmrearnsook $A O$, Theamboonlers A, Poovorawan Y. Seroprevalence of antibodies to measles, mumps, and rubella among Thai population: evaluation of measles/MMR immunization programme. J Health Popul Nutr. 2009:27(1):80-6.

6. Official Statistics of Finland (OSF): Finnish travel. Helsinki: Statistics Finland. [Acccessed 28 May 2012]. Available from: http://www.stat.fi/til/smat/index_en.html

7. ProMED-mail. [Measles (outbreak - 47 cases) - Russia (Udmurtia) (4)]. Archive Number 20120515.142692. 15 May 2012. Russian. Available from: http://www.promedmail.org/ direct.php?id=20120515.142692

8. Gustafson TL, Lievens AW, Brunell PA, Moellenberg RG, Buttery CM, Sehulster LM. Measles outbreak in a fully immunized secondary-school population. N Engl J Med. 1987;316(13):771-4.

9. Mathias RG, Meekison WG, Arcand TA, Schechter MT. The role of secondary vaccine failures in measles outbreaks. Am J Public Health. 1989;79(4):475-8.

10. Hirose M, Hidaka Y, Miyazaki C, Ueda K, Yoshikawa H. Five cases of measles secondary vaccine failure with confirmed seroconversion after live measles vaccination. Scand J Infect Dis. 1997;29(2):187-90.

11. Reyes MA, de Borrero MF, Roa J, Bergonzoli G, Saravia NG. Measles vaccine failure after documented seroconversion. Pediatr Infect Dis J. 1987;6(9):848-51.

12. Smith FR, Curran AS, Raciti KA, Black FL. Reported measles in persons immunologically primed by prior vaccination. J Pediatr. 1982;101(3):391-3.

13. Kremer JR, Schneider F, Muller CP. Waning antibodies in measles and rubella vaccinees-a longitudinal study. Vaccine. 2006;24(14):2594-601. 